\title{
Local Climate Zone Mapping: A Case Study In Belgium
}

\author{
M.L. Verdonck ${ }^{\mathrm{a}, *}$ and F. Van Coillie ${ }^{\mathrm{a}}$ \\ ${ }^{a}$ FORSIT, Faculty of Bioscience Engineering, University Ghent, Belgium- marieleen.verdonck@ ugent.be
}

KEY WORDS: Local climate zones, Landsat-8, WUDAPT, Belgium, urban, characteristic properties, OBIA

\begin{abstract}
:
Classifying a city according to the local climate zone (LCZ) scheme can provide insights into the thermal issue of urban planning. The different zones of the LCZ scheme feature particular morphological properties in terms of terrain roughness class, aspect ratio, sky view factor, surface admittance, etc. Our goal is to define the values for remote sensing and/or GIS based properties that can be used to extract local climate zones in Brussels, Belgium. The results showed similar values for LCZ 2, LCZ 3, LCZ 6, LCZ 8, LCZ 9, LCZ A, LCZ B and LCZ D compared to the zone property threshold set in the LCZ datasheets. We were not able to delineated characteristic values for aspect ratio, terrain roughness, surface admittance, albedo and Anthropogenic heat flux. Overall we can conclude that this preliminary study shows good results for the city of Brussels. More research should be done to confirm these results and to explore the OBIA approach based on these results.
\end{abstract}

\section{INTRODUCTION}

Urban areas are one of the most important human habitats (Mills, 2007). Nowadays, already 50\% of the world's population is living there and this percentage is expected to rise to $70 \%$ by 2050 (Zhou et al. 2011; UN 2012). Global warming and the increasing world population will only put more pressure on the living conditions in urban habitats (Aertsens et al. 2012; WMO 2013). From a thermal comfort point of view, it is clear that there is a need for sustainable urban planning that integrates the impact of new developments on the urban temperature regime. It is therefore key to delineate zones with a uniform thermal behaviour. Such zones were developed by Stewart and Oke (2012): local climate zones (Appendix 1, table $1)$.

\begin{tabular}{|l|l|}
\hline \multicolumn{1}{|c|}{ Built zones } & \multicolumn{1}{c|}{ Natural zones } \\
\hline \hline LCZ 1: Compact high-rise & LCZ A: Dense trees \\
\hline LCZ 2: Compact mid-rise & LCZ B: Scattered trees \\
\hline LCZ 3: Compact low-rise & LCZ C: Bush, Scrub \\
\hline LCZ 4: Open high-rise & LCZ D: Low plants \\
\cline { 1 - 1 } LCZ 5: Open mid-rise & LCZ E: Bare rock or paved \\
\hline LCZ 6: Open low-rise & LCZ F: Bare soil or sand \\
\cline { 1 - 1 } LCZ 7: Large low-rise & LCZ G: Water \\
\cline { 1 - 1 } LCZ 8: Large low-rise & \\
\cline { 1 - 1 } LCZ 9: Sparsely built & \multicolumn{1}{|c}{ Table 1. LCZ list }
\end{tabular}

Since 2015 a remote sensing based method is developed (Bechtel et al. 2015; Bechtel and Daneke 2015) to delineated LCZs in a spatial explicit manner. Verdonck et al. (in review) showed that this method might not be optimal for small heterogeneous cities. They developed a method which is based on the original one, using contextual information. One of the remaining issues of using a spatially explicit method to delineate LCZ maps is the transferability of the properties assigned to the different zones by Stewart and Oke (2012). Both methods mentioned above use visually selected training data to classify Landsat images using a random forest classifier. This selection stage is subjective and therefore we need to examine whether the zone properties derived from a spatially explicit mapping approach are conform to the thresholds set by Stewart and Oke (2012)(Appendix 2).

The objective of this preliminary study is to examine the values of the properties in the spatially explicit LCZ maps and the LCZ conceptual framework from Stewart and Oke (2012).

\section{MATERIALS AND METHODS}

\subsection{Data}

For this preliminary study we used a LCZ map of Brussels based on the method described in Verdonck et al. (in review). The map contains 10 local climate zones: LCZ 1 (Compact high-rise), LCZ 2 (Compact mid-rise), LCZ 3 (Compact lowrise), LCZ 6 (Open low-rise), LCZ 8 (Large low-rise), LCZ 9 (Sparsely built), LCZ A (Dense trees), LCZ B (Scattered trees), LCZ D (Low plants), LCZ G (Water). The remaining zones cover too small a surface to be classified correctly (LCZ 4: Open high-rise and LCZ 5: Open mid-rise) or are not present at all (LCZ 7: Large low-rise, LCZ 10: Heavy industry, LCZ C: Bush, Scrub, LCZ E: Bare rock or paved, LCZ F: Bare soil or sand)

To evaluate building height and sky view factor (SVF), high resolution Digital Surface and Digital Terrain models were used. For the region of Flanders this data is freely distributed by AGIV (AGIV, 2015). SVF maps were generated using the sky view factor tool in SAGA GIS.

Fraction maps for impervious, pervious and building surface were used to determine percentage land cover. These maps are generated using hyperspectral images for Brussels. The study area covered is visualised in figure 1 .

\footnotetext{
* Corresponding author
} 


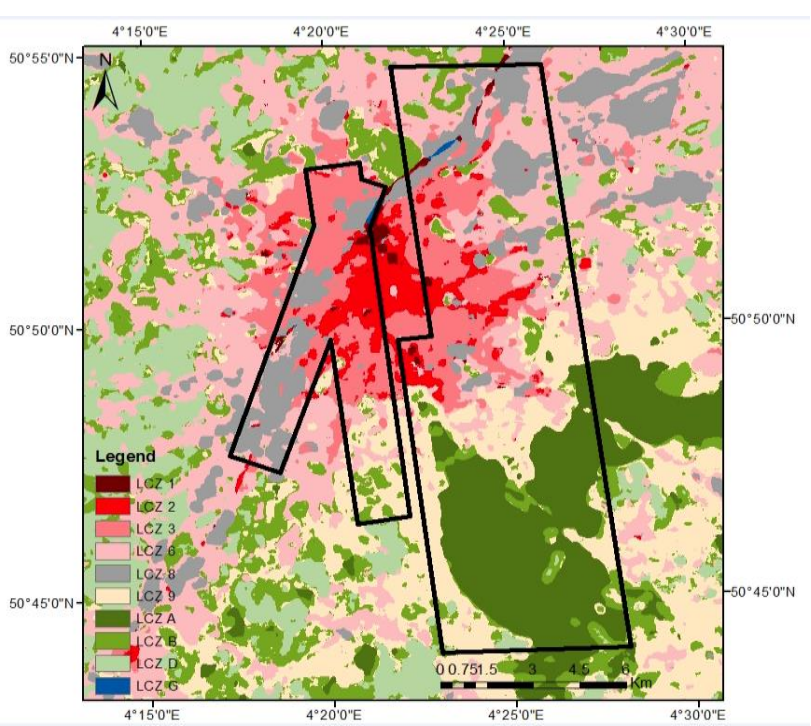

Figure 1. Visualised study area on spatially explicit LCZ map

\subsection{Method}

Seeing as this is a preliminary study we only evaluated 5 properties (SVF, building/tree height, Building surface fraction, Impervious surface fraction, pervious surface fraction) for a small portion of Brussels. For each LCZ the mean value and the standard deviation of each property is calculated.

\section{RESULTS AND DISCUSSION}

The values for the properties based on the spatially explicit LCZ map are shown in table 2 .

\begin{tabular}{|c|c|c|c|c|c|c|c|c|c|c|}
\cline { 2 - 12 } \multicolumn{1}{c|}{} & \multicolumn{2}{|c|}{ SVF } & \multicolumn{2}{c|}{$\begin{array}{c}\text { Building } \\
\text { Height }\end{array}$} & \multicolumn{2}{c|}{$\begin{array}{c}\text { Building } \\
\text { Fraction }\end{array}$} & \multicolumn{2}{c|}{$\begin{array}{c}\text { Impervious } \\
\text { Fraction }\end{array}$} & \multicolumn{2}{c|}{$\begin{array}{c}\text { Pervious } \\
\text { Fraction }\end{array}$} \\
\cline { 2 - 12 } \multicolumn{1}{c|}{} & M & S & M & S & M & S & M & S & M & S \\
\hline LCZ 1 & 0.70 & 0.20 & 18.41 & 11.37 & 0.27 & 0.31 & 0.27 & 0.28 & 0.45 & 0.38 \\
\hline LCZ 2 & 0.59 & 0.21 & 16.03 & 9.80 & 0.46 & 0.30 & 0.29 & 0.25 & 0.24 & 0.27 \\
\hline LCZ 3 & 0.61 & 0.20 & 11.10 & 5.77 & 0.49 & 0.27 & 0.25 & 0.23 & 0.25 & 0.26 \\
\hline LCZ 6 & 0.76 & 0.18 & 10.06 & 6.33 & 0.22 & 0.23 & 0.22 & 0.23 & 0.56 & 0.31 \\
\hline LCZ 8 & 0.82 & 0.17 & 10.27 & 5.99 & 0.34 & 0.34 & 0.37 & 0.30 & 0.29 & 0.30 \\
\hline LCZ 9 & 0.67 & 0.19 & 9.89 & 6.26 & 0.14 & 0.18 & 0.10 & 0.16 & 0.75 & 0.25 \\
\hline LCZ A & 0.29 & 0.22 & 15.91 & 10.06 & 0.00 & 0.04 & 0.06 & 0.09 & 0.93 & 0.10 \\
\hline LCZ B & 0.73 & 0.22 & 10.40 & 7.19 & 0.04 & 0.11 & 0.08 & 0.16 & 0.87 & 0.22 \\
\hline LCZ D & 0.90 & 0.13 & 5.25 & 3.37 & 0.01 & 0.05 & 0.03 & 0.09 & 0.95 & 0.13 \\
\hline LCZ G & 0.87 & 0.12 & 9.17 & 4.38 & 0.09 & 0.19 & 0.15 & 0.22 & 0.75 & 0.33 \\
\hline
\end{tabular}

Table 2. Properties based on the spatially explicit LCZ map for Brussels $(\mathrm{M}=$ mean, $\mathrm{S}=\mathrm{STDEV})$

The results show that most properties fit between the thresholds set by Stewart and Oke (2012) (Appendix 2). Some of the zones such as LCZ 1 and LCZ G do not fit the scheme. Both zones only cover a small surface area in the study area, it was also shown by Verdonck et al. (in review) that these zones were not wel classified. Next to that we see high standard deviations for building height. This is due to the heterogeneous nature of the study area.

\section{CONCLUSION}

The results of this preliminary study show that a visual selection of training data does result in a spatial explicit LCZ map with property values ranging between the thresholds set by Stewart and Oke (2012). Further research should be conducted to analyse whether valuable maps can be produced using an Object based method.

\section{ACKNOWLEDGEMENTS}

We thank USGS, the NASA and AGIV for the freely available Landsat and Lidar data. We also thank the Belgian Federal Science Policy Office for providing research funds to make this research, as part of the UrbanEARS project, possible.

\section{REFERENCES}

Aertsens J., De Nocker L., Lauwers H., Norga K., Simoens I., Meiresanne L., Turkelboom F. \& Broekx S., 2012. Daarom Groen! Waarom u wint bij groen in u stad of gemeente. Studie uitgevoerd in opdracht van: ANB-Afdeling Natuur en Bos

Agentschap voor Geografische informatie Vlaanderen, 2015. Standaardproducten Digitaal Hoogtemodel II. https://download.agiv.be/Producten/Detail?id=966\&title=Stand aardproducten_Digitaal_Hoogtemodel_Vlaanderen_II (1 July 2016)

Bechtel, B.; Alexander, P.; Böhner, J.; Ching, J.; Conrad, O.; Feddema, J.; Mills, G.; See, L.; Stewart, I., 2015. Mapping Local Climate Zones for a Worldwide Database of the Form and Function of Cities. ISPRS Int. J. Geo-Information, 4, pp. 199 219.

Bechtel, B.; Daneke, C., 2012. Classification of local climate zones based on multiple earth observation data. IEEE J. Sel. Top. Appl. Earth Obs. Remote Sens., 5, pp. 1191-1202.

Mills, G., 2007. Cities as agents of global change. International journal of climatology, 27, pp. 1847-1857

Stewart, I. D., \& Oke, T. R. , 2012. Local climate zones for urban temperature studies. Bulletin of the American Meteorological Society, 93(12), pp. 1879-1900.

UN, United Nations, Department of Economic and Social Affairs, 2012. World Urbanization Prospects, the 2011 Revision. Highlights. New York

Verdonck M.L., Okujeni A., van der Linden S., Demuzere M., De Wulf R. and Van Coillie F., (in review). Influence of neighbourhood on 'Local Climate Zone' mapping in heterogeneous cities. Remote Sensing

World Meteorological Organization, 2013. The global climate 2001- 2010 a decade of climate extremes summary report

Zhou W., Huang G. \& Cadenasso M.L., 2011. Does spatial configuration matter? Understanding the effects of land cover pattern on land surface temperature in urban landscapes. Landscape and urban planning ,102, pp. 54-63 


\section{APPENDIX}

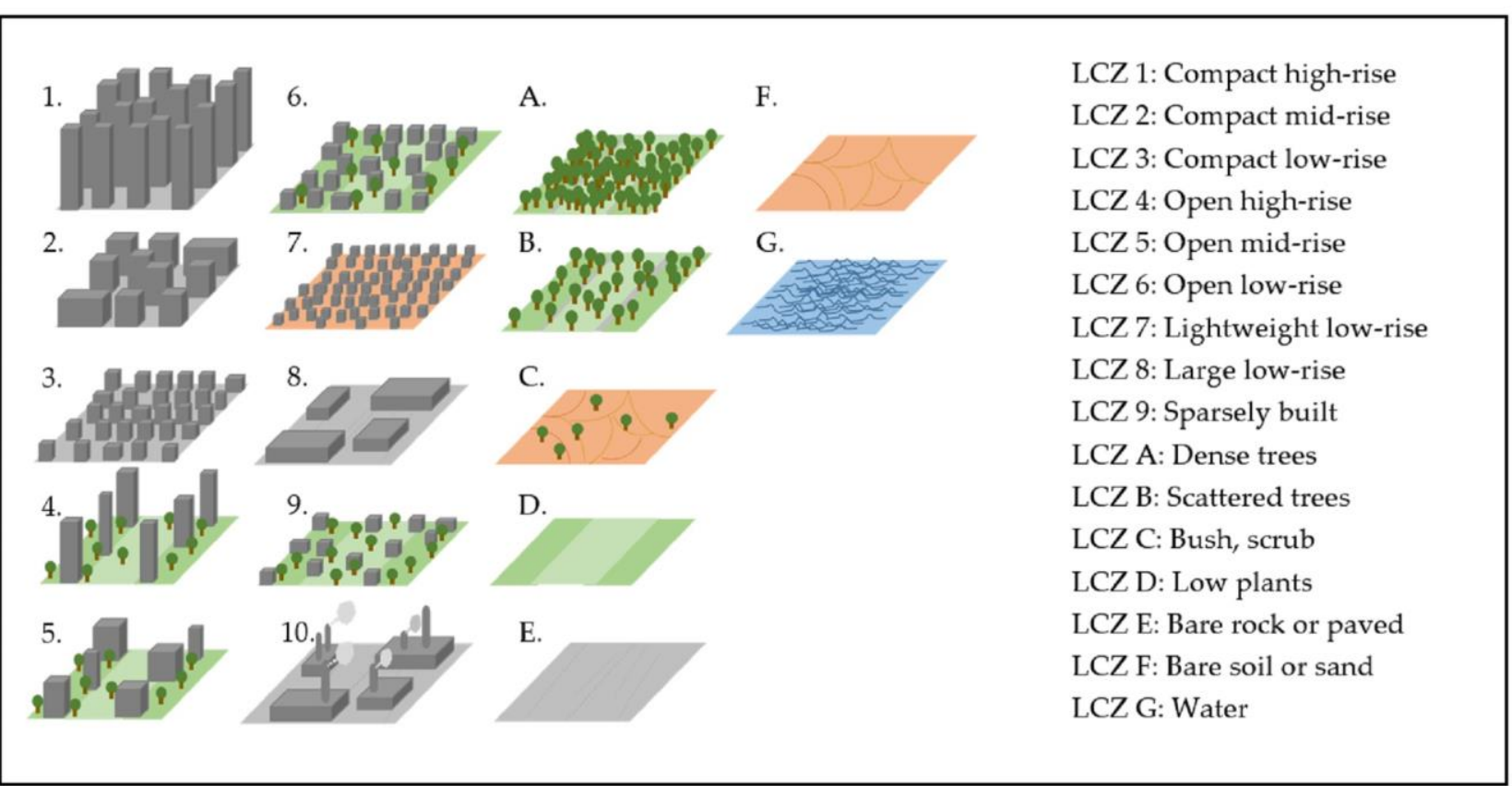

Appendix 1. LCZ scheme

\begin{tabular}{|c|c|c|c|c|c|c|c|c|c|c|c|c|c|c|c|c|c|}
\hline & LCZ 1 & LCZ 2 & LCZ 3 & LCZ 4 & LCZ 5 & LCZ 6 & LCZ 7 & LCZ 8 & LCZ 9 & LCZ 10 & LCZ A & LCZ B & LCZ C & LCZ D & LCZ E & LCZ F & LCZ G \\
\hline SVF & $0.2-0.4$ & $0.3-0.6$ & $0.2-0.6$ & $0.5-0.7$ & $0.5-0.8$ & $0.6-0.9$ & $0.2-0.5$ & $0.7-1$ & $0.8-1$ & $0.6-0.9$ & $0-0.4$ & $0.5-0.8$ & $0.9-1$ & $0.9-1$ & $0.9-1$ & $0.9-1$ & $0.9-1$ \\
\hline Aspect ratio & $2-3$ & $0.75-2$ & $\begin{array}{c}0.75- \\
1.5 \\
\end{array}$ & $\begin{array}{c}0.75- \\
1.25 \\
\end{array}$ & $0.3-0.75$ & $0.3-0.75$ & $1-2$ & $0.1-0.3$ & $0.1-0.25$ & $0.2-0.5$ & $1-3$ & $\begin{array}{c}0.25- \\
0.75 \\
\end{array}$ & $0.25-0.3$ & $0-0.1$ & $0-0.1$ & $0-0.1$ & $0-0.1$ \\
\hline Building/Tree height (m) & $25-50$ & $10-25$ & $3-10$ & $25-50$ & $10-25$ & $3-10$ & $2-4$ & $3-10$ & $3-10$ & $5-15$ & $3-30$ & $3-15$ & $0-2$ & $0-1$ & $0-0.25$ & $0-0.25$ & $0-0.25$ \\
\hline Terrain roughness class & 8 & $6-7$ & 6 & $7-8$ & $5-6$ & $5-6$ & $4-5$ & 5 & $5-6$ & $5-6$ & 8 & $5-6$ & $4-5$ & $3-4$ & $1-2$ & $1-2$ & 1 \\
\hline Building surface fraction $(\%)$ & $40-60$ & $40-70$ & $40-70$ & $20-40$ & $20-40$ & $20-40$ & $60-90$ & $30-50$ & $10-20$ & $20-30$ & $0-10$ & $0-10$ & $0-10$ & $0-10$ & $0-10$ & $0-10$ & $0-10$ \\
\hline Impervious surface fraction (\%) & $40-60$ & $30-50$ & $20-50$ & $30-40$ & $30-50$ & $20-50$ & $0-20$ & $40-50$ & $0-20$ & $20-40$ & $0-10$ & $0-10$ & $0-10$ & $0-10$ & $90-100$ & $0-10$ & $0-10$ \\
\hline Pervious surface fraction $(\%)$ & $0-10$ & $0-20$ & $0-30$ & $30-40$ & $20-40$ & $30-60$ & $0-30$ & $0-20$ & $60-80$ & $40-50$ & $90-100$ & $90-100$ & $90-100$ & $90-100$ & $0-10$ & $90-100$ & $90-100$ \\
\hline Surface admittance $\left(\mathrm{Jm}^{-2} \mathbf{S}^{1 / 2} \mathbf{K}^{-1)}\right.$ & $\begin{array}{l}1100- \\
2200\end{array}$ & $\begin{array}{l}1100- \\
2200\end{array}$ & $\begin{array}{l}1000- \\
2200\end{array}$ & $\begin{array}{l}1100- \\
2200\end{array}$ & $\begin{array}{l}1000- \\
2200 \\
\end{array}$ & $\begin{array}{l}1000- \\
2200\end{array}$ & $\begin{array}{l}400- \\
1800 \\
\end{array}$ & $\begin{array}{l}1000- \\
2000\end{array}$ & $\begin{array}{l}1000- \\
2200\end{array}$ & $\begin{array}{l}1000- \\
2500 \\
\end{array}$ & $\begin{array}{c}1000- \\
1800 \\
\end{array}$ & $\begin{array}{c}1000- \\
1800\end{array}$ & $\begin{array}{l}1000- \\
1800 \\
\end{array}$ & $\begin{array}{l}1000- \\
1800 \\
\end{array}$ & $\begin{array}{l}1300- \\
3000\end{array}$ & $\begin{array}{c}1000- \\
1800\end{array}$ & 1500 \\
\hline Albedo & $0.1-0.2$ & $0.1-0.2$ & $0.1-0.2$ & $\begin{array}{l}0.12- \\
0.25 \\
\end{array}$ & $\begin{array}{l}0.12- \\
0.25 \\
\end{array}$ & $\begin{array}{l}0.12- \\
0.25 \\
\end{array}$ & $\begin{array}{l}0.15- \\
0.35 \\
\end{array}$ & $\begin{array}{l}0.15- \\
0.25 \\
\end{array}$ & $\begin{array}{l}0.12- \\
0.25 \\
\end{array}$ & $0.12-0.2$ & $0.1-0.2$ & $\begin{array}{l}0.15- \\
0.25 \\
\end{array}$ & $0.15-0.3$ & $\begin{array}{l}0.15- \\
0.25 \\
\end{array}$ & $\begin{array}{l}0.15- \\
0.25 \\
\end{array}$ & $\begin{array}{l}0.20- \\
0.35 \\
\end{array}$ & $0.02-0.1$ \\
\hline Anthropogenic heat flux $\left(\mathrm{Wm}^{-2}\right)$ & $50-300$ & $50-300$ & $0-75$ & $0-50$ & $0-25$ & $0-25$ & $0-35$ & $0-50$ & $0-10$ & $0-300$ & 0 & 0 & 0 & 0 & 0 & 0 & 0 \\
\hline
\end{tabular}

